\title{
FAKTOR-FAKTOR YANG MEMPENGARUHI PARTISIPASI MASYARAKAT DALAM MEREDUKSI SAMPAH RUMAH TANGGA DI KOTA BOGOR
}

\section{FACTORS AFFECTING COMMUNITY PARTICIPATION IN HOUSEHOLD WASTE REDUCTION IN BOGOR CITY}

\author{
Aditya Pandu Nugraha ${ }^{1}$, Hartrisari Hardjomidjojo ${ }^{2}$, dan Jono M Munandar ${ }^{3}$ \\ ${ }^{1}$ Pasca Sarjana Program Studi Ilmu Manajemen, Sekolah Pascasarjana IPB, Jl. Raya Dramaga, Babakan, \\ Kec. Dramaga, Bogor, Jawa Barat 16680, e-mail: aditya_0471@apps.ipb.ac.id \\ ${ }^{2}$ Departemen Teknologi Industri Pertanian, FATETA-IPB Jl. Raya Dramaga, Babakan, \\ Kec. Dramaga, Bogor, Jawa Barat 16680, e-mail: sari@biotrop.net \\ ${ }^{3}$ Departemen Manajemen, FEM-IPB, Jl. Raya Dramaga, Babakan, Kec. Dramaga, Bogor, Jawa Barat 16680, \\ e-mail: jonomu@apps.ipb.ac.id
}

Diterima tanggal 2 September 2019, disetujui tanggal 16 April 2020

\begin{abstract}
ABSTRAK
Pengelolaan sampah perkotaan telah menjadi permasalahan global dan tidak terkecuali di Kota Bogor. Saat ini sekitar 150-180 ton sampah padat per hari tidak dapat terangkut ke Tempat Pembuangan Akhir (TPA) Galuga dan tersisa di dalam kota Bogor. Pemerintah Kota Bogor telah mengelola sampah padat perkotaannya dengan berlandaskan Undang-Undang Nomor 18/2008 yakni berupaya mereduksi sampah dari sumber terbesar, yaitu rumah tangga permukiman. Dalam upaya mereduksi sampah, pemerintah Kota Bogor telah membentuk Bank Sampah serta menyediakan komposter di perumahan. Terdapat 255 Bank Sampah unit terdaftar di Bank Sampah Induk Berbasis Aparatur (BASIBA) Kota Bogor, namun hanya 43 unit yang aktif dengan total reduksi kurang dari $1 \%$ timbulan sampah bulanan. Riset ini bertujuan untuk mengukur persepsi masyarakat terhadap pengolahan sampah melalui Bank Sampah serta memodelkan alternatif skenario yang paling efektif dan memungkinkan untuk mengurangi timbulan sampah padat rumah tangga. Penelitian ini menggunakan analisis korelasi untuk analisis persepsi serta prinsip-prinsip sistem dinamik untuk permodelan. Analisis terhadap 196 sampel responden menunjukkan bahwa bahwa faktor usia dan tingkat pendidikan memiliki dampak paling signifikan dalam partisipasi masyarakat terhadap pengolahan dan mereduksi sampah melalui Bank Sampah. Kombinasi optimasi Bank Sampah dan edukasi terhadap partisipasi masyarakat dalam mereduksi timbulan sampah melalui Bank Sampah diperkirakan dapat mengurangi timbulan sampah tak terangkut sebesar 18\% dalam jangka waktu lima tahun.
\end{abstract}

Kata kunci: Korelasi, reduksi timbulan, sampah padat, simulasi.

\begin{abstract}
Urban waste management has become a global problem, including in Bogor City. Currently, about 150-180 tons of solid waste per day cannot be transported to the final disposal (TPA) Galuga and still left in Bogor City. To overcome municipal waste issues, Bogor City administrator has managed its solid waste using Act of the Republic of Indonesia Number 18/2008, regarding waste reduction directly from its source, the most significant solid waste contributor which is household settlements. To reduce its solid waste, Bogor City administrator has initiated Waste Bank and provides composters in several settlements. There are 255 waste Bank units registered in the Central Waste Bank (BASIBA) Bogor, but only 43 listed as active, with less than 1\% reduction of total monthly waste generation. This research aims to identify and measure public perception of processing their solid waste using Waste Bank and model alternative scenarios that are most effective and possible to reduce household solid waste. This research uses correlation analysis for perception analysis as well as dynamic system principles for modeling. The analysis of 196 sample respondents revealed that the age and education level had the most significant impact on public participation in processing and waste reduction by Waste Bank. The combination of optimizing Waste Bank and educating the community on participation in reducing waste generation using Waste Bank is expected to reduce the unmanaged waste by $18 \%$ in the five years.
\end{abstract}

Keywords: Correlation, reduction, simulation, solid waste. 


\section{PENDAHULUAN}

Sistem pengelolaan dan pembuangan sampah perkotaan yang baik merupakan hal yang krusial. Manajemen pengelolaan sampah perkotaan merupakan hal kompleks, meliputi berbagai dimensi seperti keuangan, teknis, hukum, lingkungan, penataan lingkungan, sosial budaya serta keterlibatan para pemangku kepentingan. Masing-masing dimensi terkait erat dan saling memberikan umpan balik [1].

Lokasi kota Bogor yang relatif dekat dengan Jakarta dan akses yang memadai menarik minat orang untuk tinggal di Kota Bogor, menyebabkan pertumbuhan penduduk di Kota Bogor. Kedekatan lokasi dengan Jakarta juga membawa dampak ke pertumbuhan ekonomi Kota Bogor yang ditunjukkan dengan peningkatan angka Pendapatan Regional Domestik Bruto (PRDB) selama 3 tahun terakhir [2-4]. Pengolahan sampah di Kota Bogor telah menggunakan metode berbasis komunitas sesuai arahan UU Nomor 18/2008 tentang Pengelolaan Sampah pasal 22 [5]. Dinas Lingkungan Hidup Kota Bogor dan tim BASIBA (Bank Sampah Induk Berbasis Aparatur) Pemerintah Kota Bogor berupaya mengurangi timbunan sampah di tingkat masyarakat yang diinisiasi dengan dasar swadaya masyarakat. Bank sampah merupakan konsep pengumpulan dan pemilahan sampah kering yang memiliki manajemen bank penyimpanan sampah [6].

Berdasarkan wawancara awal dengan narasumber di Dinas Lingkungan Hidup, timbulan sampah kota Bogor mencapai 600 ton per hari, atau sekitar 18.000 ton per bulan. Sebanyak $74 \%$ dari timbulan sampah (sekitar 450-475 ton/hari) dibuang ke Tempat Pembuangan Akhir (TPA) Galuga, dan $26 \%$ dari timbulan sampah harian tersebut (sekitar 150 ton/hari) tidak dapat terangkut dan tersisa di dalam kota Bogor.

Dalam dokumen Rencana Pembangunan Jangka Menengah Daerah (RJPMD)
Kota Bogor periode 2015-2019, Dinas Lingkungan Hidup (DLH) diamanatkan untuk mencapai target reduksi sampah padat sebesar $20 \%$ pada tahun 2019 , dengan target pengurangan sebesar 5\% setiap tahunnya. Pembentukan Bank Sampah berdasarkan RPJMD ditargetkan sebanyak 15 buah setiap tahun sehingga total bank sampah pada tahun 2019 di Kota Bogor direncanakan berjumlah 85 unit. Pada akhir Desember 2018 telah terbentuk 255 Bank Sampah Unit dan 1 Bank Sampah Induk di Kota Bogor. Akan tetapi, dengan adanya 255 Bank Sampah Unit, komposter dan Tempat Pembuangan Sampah 3R (Recycle, Reuse, Reduce) atau TPS3R hanya mampu mereduksi angka timbulan sampah disumbernya pada angka kisaran $500 \mathrm{~kg} /$ hari atau kurang dari 1\% [7]. Rendahnya angka reduksi sampah disaat bersamaan jumlah unit Bank Sampah sudah melampaui target menjadi permasalahan yang dikaji dalam penelitian ini. Pada penelitian lain di Kediri, penyediaan komposter untuk mengelola sampah rumah tangga dengan berbasis partisipasi masyarakat juga telah dimulai, namun dampaknya juga tidak efektif [8].

Penelitian ini dilakukan untuk mengetahui tentang a) partisipasi masyarakat terhadap pengelolaan sampah rumah tangga berbasis komunitas (Bank Sampah dan komposter) dan reduksi timbulan sampah rumah tangga, b) permodelan sistem pengelolaan sampah rumah tangga berbasis komunitas, dan c) skenario kebijakan pengelolaan sampah rumah tangga berbasis komunitas di kota Bogor. Tujuan riset ini adalah mencari skenario terbaik untuk mengurangi jumlah sampah tersisa di dalam kota yang tidak terangkut.

Batasan serta ruang lingkup penelitian ini ada dua. Pertama, strategi reduksi sampah yang dimaksud dalam penelitian ini adalah mengelola sampah padat rumah tangga secara swadaya dengan konsep 3R, yang difasilitasi Bank Sampah Unit, Bank Sampah Induk Berbasis Aparatur 
(BASIBA), penggunaan komposter, serta keberadaan pemulung. Kedua, penelitian ini mengasumsikan seluruh sampah padat rumah tangga berasal dari permukiman rumah tangga masyarakat dan tidak menghitung sumber timbulan sampah lain di luar rumah tangga yang berada dalam area permukiman tersebut.

\section{METODOLOGI}

\section{Alur pikir penelitian}

Jumlah timbulan sampah yang dihasilkan di kota Bogor telah melebihi jumlah sampah yang dapat diangkut oleh Dinas Lingkungan Hidup dan Kebersihan Kota Bogor setiap harinya. Pemerintah kota Bogor telah melakukan upaya-upaya untuk mereduksi timbulan sampah yang diangkut. Diantaranya melalui kegiatan berbasis komunitas (Bank Sampah, Komposter) [7] serta membuat regulasi untuk mengurangi timbulan sampah, salah satunya melalui Peraturan Walikota Bogor (10) No 61/2018. Pada saat penelitian ini dilakukan terdapat 255 Bank Sampah Unit, namun hanya mampu mereduksi kurang dari 1\% sampah harian. Penelitian ini mencoba mencari faktor-faktor yang berkorelasi terhadap partisipasi masyarakat terhadap pengelolaan sampah rumah tangga berbasis komunitas serta memodelkan skenario yang paling efektif dalam mengurangi jumlah sampah padat yang tidak terangkut di kota Bogor.

\section{Waktu dan lokasi penelitian}

Penelitian dilakukan pada bulan Februari-Mei 2018. Lokasi penelitian di Kota Bogor. Pengambilan sampel dilakukan pada 6 (enam) kecamatan yaitu Bogor Tengah, Bogor Selatan, Bogor Timur, Bogor Utara, Bogor Barat, dan Tanah Sareal.

\section{Pengumpulan data}

Data primer diperoleh melalui wawancara mendalam terhadap pemangku kepentingan yang memiliki keterlibatan dalam pengelolaan sampah kota. Data sekunder berasal dari dokumen publikasi resmi badan pemerintah kota terkait pengelolaan sampah perkotaan. Jumlah sampel ditentukan dengan metode Cochran, untuk menghitung ukuran sampel ideal dengan tingkat presisi yang diinginkan, tingkat keyakinan yang diinginkan (confidence level) dalam populasi [9].

$$
\eta_{0}=\frac{\mathrm{Z}^{2} p q}{1+\left(\frac{\mathrm{Z}^{2} p q}{e^{2} \mathrm{~N}}\right)}
$$

Pers 1. Formula penentuan jumlah sampel [9].

Penelitian ini menggunakan Margin of Error (e) 7.5\%, selang kepercayaan 95\%, besar populasi sebanyak 1.081 .000 jiwa $(\mathrm{N})$ dengan proporsi $(p) 50 \%$ serta nilai tabel $\mathrm{Z}$ sebesar 1,96 untuk selang kepercayaan 95\%. Formula tersebut menghasilkan jumlah sampel diperlukan sebesar 171 responden. Untuk menghindari resiko kekurangan data saat tahap data cleaning, jumlah sampel ditambahkan menjadi 200 responden. Pengambilan sampel dilakukan secara random sampling terhadap masyarakat yang tinggal di Kota Bogor dan dibagi kedalam 6 kecamatan di Kota Bogor. Pengambilan data dilakukan melalui wawancara mendalam. Pada tahap data cleaning, hanya terdapat 196 sampel yang memenuhi syarat untuk analisis.

\section{Metode pengolahan dan analisis data}

Pengolahan data dalam penelitian ini dibagi menjadi dua tahap. Tahap pertama untuk menganalisis partisipasi masyarakat menggunakan uji korelasi. Uji korelasi digunakan untuk mendapatkan hubungan antara variabel-variabel bebas dengan variabel terikat. Variabel bebas yang digunakan adalah usia, pendidikan, status tempat tinggal dan durasi tinggal [10-13]. Variabel-variabel terikat (dependent) adalah partisipasi dalam mengikuti kegiatan Bank Sampah dan Komposter, serta partisipasi 
dalam mereduksi timbulan sampahnya sendiri. Tahap kedua menggunakan prinsipprinsip pendekatan systems thinking untuk memodelkan penambahan timbulan sampah berdasarkan beberapa skenario.

\section{III.HASIL DAN PEMBAHASAN}

\section{Demografi Responden}

Responden pada penelitian ini terdiri dari 196 orang, dengan pembagian di setiap kecamatan terlihat pada Tabel 1, sementara sebaran demografi responden menunjukkan bahwa mayoritas responden merupakan perempuan (Gambar 1), dan usia responden mayoritas berada pada rentang usia 31-40 tahun (Gambar 2).

Tingkat pendidikan responden didominasi oleh lulusan SMA/SMK (Gambar 3), dan responden paling banyak bertempat tinggal di rumah kontrakan

Tabel 1. Jumlah Responden per Kecamatan

\begin{tabular}{lc}
\hline Kecamatan & Responden \\
\hline Bogor Barat & 35 \\
Bogor Selatan & 28 \\
Bogor Tengah & 32 \\
Bogor Timur & 31 \\
Bogor Utara & 32 \\
Tanah Sareal & 38 \\
Total & 196 \\
\hline
\end{tabular}

Sumber: Pengolahan data (2019)

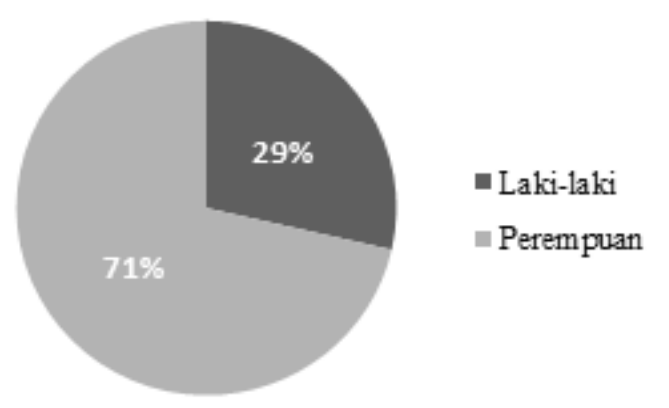

Gambar 1. Jenis kelamin responden

Sumber: Pengolahan data (2019)

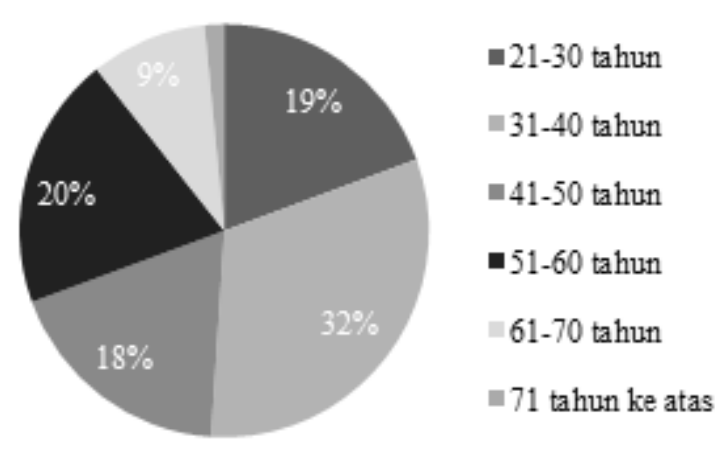

Gambar 2. Usia responden

Sumber: Pengolahan data (2019)

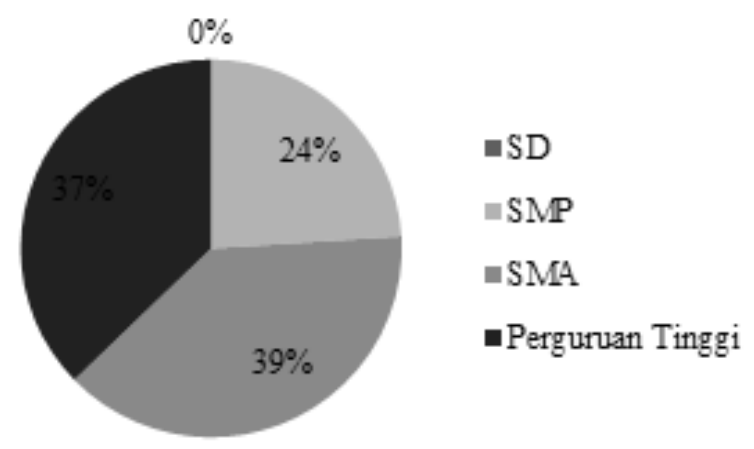

Gambar 3. Tingkat pendidikan responden Sumber: Pengolahan data (2019)

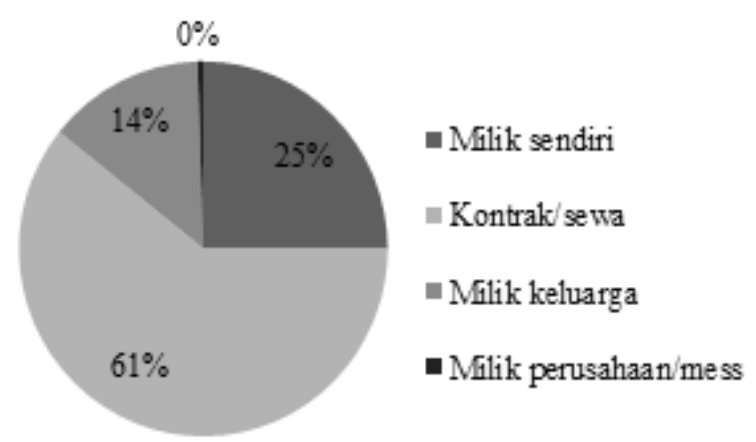

Gambar 4. Status tempat tinggal

Sumber: Pengolahan data (2019)

dengan durasi tinggal selama lebih dari 5 tahun (Gambar 4 dan 5).

Upaya masyarakat dalam pengurangan sampah di Kota Bogor terbagi atas 2 (dua), yaitu kegiatan partisipasif dalam pengelolaan sampah berbasis komunitas (bank sampah komposer) dan pengurangan timbulan sampah. Sebanyak 56 responden $(28,57 \%)$ 


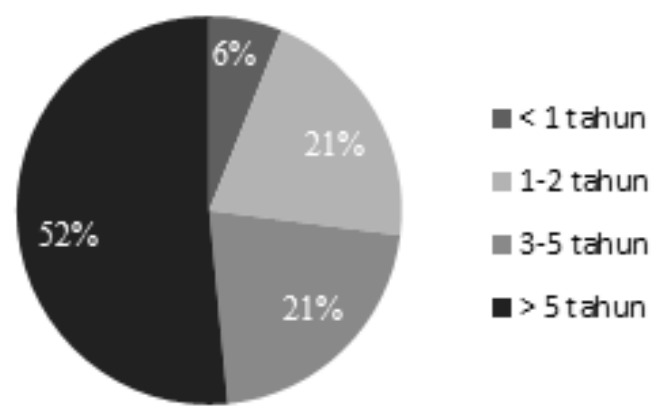

Gambar 5. Durasi tinggal responden

Sumber: Pengolahan data (2019)

mengaku sudah berpartisipasi dalam pengelolaan sampah berbasis komunitas (Bank Sampah dan/atau Komposter). Angka yang relatif rendah ini terkait dengan minimnya pengetahuan responden mengenai Bank Sampah dan manfaat Bank Sampah (26\%), keengganan mengikuti program Bank Sampah karena repot/tidak terbiasa (34\%), karena alasan jauh (28\%), kotor $(10 \%)$ serta sisanya (2\%) alasan lain (Gambar 6). Tabel 2 menunjukkan jumlah responden yang mengelola sampah rumah tangga mereka berbasis komunitas dan/atau sudah mengurangi timbulan sampahnya. Sebanyak 77 responden (39\%) mengaku telah berpartisipasi dalam mengurangi timbulan sampah, baik berupa mengurangi penggunaan plastik pembungkus dan plastik kemasan, hingga upaya-upaya mengurangi timbulan sampah pribadi responden.

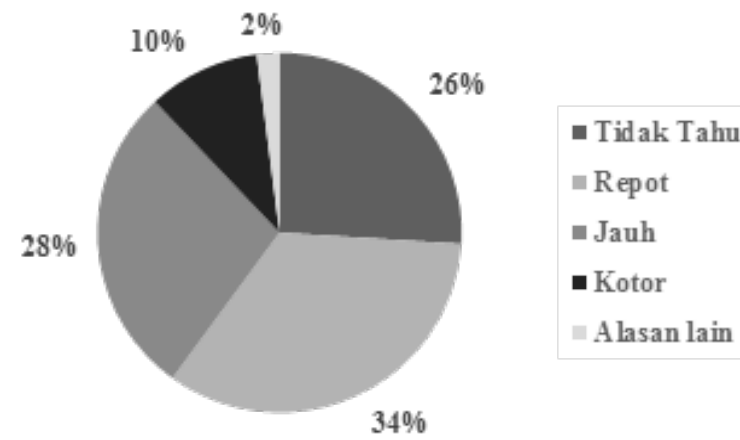

Gambar 6. Alasan responden tidak berpartisipasi dalam Bank Sampah

Sumber: Pengolahan data (2019)

Kesadaran masyarakat ini diduga terkait dengan Peraturan Walikota Bogor Nomor 61/2018 tentang Larangan Penggunaan Kantong Plastik di Wilayah Kota Bogor [14]. Regulasi ini menyebabkan warga tidak mendapatkan kantong plastik, dan beralih ke tote bag (tas jinjing) atau kardus untuk wadah berbelanja. Hal ini dianggap responden sudah berpartisipasi dalam mengurangi timbulan sampah mereka.

\section{Analisis Pengaruh Variabel Bebas terhadap Variabel Terikat}

Hasil analisis terhadap variabel pendidikan dan usia terhadap partisipasi pengelolaan sampah melalui Bank Sampah keduanya menunjukkan angka signifikansi p-value kurang dari $\alpha=0,05$ seperti yang terlihat di Tabel 3.

Tabel 2. Jumlah responden yang berpartisipasi dalam pengelolaan sampah melalui Bank Sampah dan/ atau sudah berupaya mengurangi timbulan sampahnya.

\begin{tabular}{lcc}
\hline \multicolumn{1}{c}{ Kecamatan } & $\begin{array}{r}\text { Pengelolaan sampah berbasis } \\
\text { komunitas (orang) }\end{array}$ & $\begin{array}{c}\text { Pengurangan timbulan sampah } \\
\text { (orang) }\end{array}$ \\
\hline Bogor Barat & 13 & 10 \\
Bogor Selatan & 7 & 9 \\
Bogor Tengah & 9 & 13 \\
Bogor Timur & 7 & 13 \\
Bogor Utara & 2 & 18 \\
Tanah Sareal & 18 & 14 \\
\hline Total & 56 & 77 \\
\hline
\end{tabular}

Sumber: Pengolahan data (2019) 
Tabel 3. Rekapitulasi nilai $P$ value hubungan variabel bebas terhadap variabel terikat partisipasi masyarakat dalam program Bank Sampah di komunitasnya

\begin{tabular}{lcccc}
\hline \multicolumn{1}{c}{ Kecamatan } & Usia & Pendidikan & $\begin{array}{c}\text { Status Tempat } \\
\text { Tinggal }\end{array}$ & Durasi Tempat Tinggal \\
\hline Bogor Utara & 0.617 & 0.628 & 0.699 & 0.219 \\
Bogor Selatan & 0.737 & 0.152 & 0.508 & 0.511 \\
Bogor Barat & 0.323 & 0.254 & 0.854 & $0.057^{*}$ \\
Bogor Timur & 0.418 & 0.904 & 0.414 & 0.352 \\
Bogor Tengah & 0.232 & 0.292 & 0.656 & 0.458 \\
Tanah Sareal & 0.298 & 0.326 & 0.116 & 0.308 \\
\hline Kota Bogor & 0.154 & $0.021^{*}$ & 0.373 & 0.201 \\
\hline
\end{tabular}

Sumber: Pengolahan Data (2019)

Tabel 4 Rekapitulasi signifikansi (p-value) hubungan variabel terhadap variabel Reduksi Timbulan Sampah Harian (reduce).

\begin{tabular}{lllcc}
\hline \multicolumn{1}{c}{ Kecamatan } & \multicolumn{1}{c}{ Usia } & Pendidikan & $\begin{array}{c}\text { Status Tempat } \\
\text { Tinggal }\end{array}$ & $\begin{array}{c}\text { Durasi Tempat } \\
\text { Tinggal }\end{array}$ \\
\hline Bogor Utara & 0.368 & $0.020^{* *}$ & 0.589 & 0.533 \\
Bogor Selatan & 0.790 & 0.961 & 0.227 & 0.688 \\
Bogor Barat & $0.049 * *$ & 0.609 & $0.057^{*}$ & 0.881 \\
Bogor Timur & 0.429 & 0.343 & 0.490 & 0.560 \\
Bogor Tengah & 0.144 & 0.265 & $0.092^{*}$ & 0.148 \\
Tanah Sareal & - & - & - & - \\
Kota Bogor & 0.242 & 0.634 & 0.197 & 0.175 \\
\hline
\end{tabular}

Sumber: Pengolahan Data (2019)

*Signifikan

** Sangat Signifikan

Hasil ini mengindikasikan bahwa variabel pendidikan dan usia memiliki hubungan yang signifikan terhadap partisipasi masyarakat mengikuti pengolahan sampah yang berbasis komunitas. Responden yang memiliki pendidikan yang lebih tinggi dan/atau usia yang lebih tinggi memiliki partisipasi lebih baik dalam mengikuti kegiatan pengolahan sampah berbasis komunitas di lingkungannya. Hal ini sesuai dengan riset oleh Ramandhani [15] bahwa kelompok responden dengan pendidikan dan pengetahuan lebih tinggi memiliki tingkat timbulan sampah yang lebih rendah [16]. Pengetahuan lebih tinggi pada ibu rumah tangga juga menunjukkan hasil yang signifikan dalam perilaku mengelola limbah plastik rumah tangga mereka [13].
Analisis per kecamatan lebih dalam menunjukkan hasil yang berbeda. Pada Kecamatan Bogor Barat, durasi tinggal responden di wilayah tersebut berkorelasi signifikan, menunjukkan bahwa responden yang lebih lama tinggal di suatu wilayah yang sama cenderung memiliki partisipasi yang lebih tinggi dalam mengikuti kegiatan Bank Sampah untuk mereduksi sampah berbasis komunitas di lingkungannya.

Pada Tabel 4 terlihat kegiatan partisipasi pengurangan timbulan sampah harian (reduce), apabila dianalisis untuk Kota Bogor secara keseluruhan, tidak ada satu pun variabel yang signifikan. Akan tetapi apabila dianalisis per kecamatan, maka terdapat hubungan beberapa variabel yang signifikan terhadap variabel partisipasi 
reduksi. Perbedaan ini dapat muncul karena faktor-faktor dominan yang mempengaruhi korelasi responden pada masing-masing kecamatan berbeda-beda [17].

Pada Tabel 4 terlihat bahwa di Kecamatan Bogor Utara, tingkat pendidikan memiliki hubungan signifikan terhadap partisipasi masyarakat dalam mengurangi timbulan sampahnya. Di Kecamatan Bogor Barat, terdapat hubungan antara usia responden dengan partisipasi masyarakat dalam mereduksi sampah mereka. Hal ini menunjukkan semakin senior usia responden, maka kesadaran mereka untuk mengurangi timbulan sampah semakin tinggi. Pada saat proses wawancara pengambilan data diketahui bahwa responden berusia senior memahami dan tanpa disadari telah melakukan reduksi sampah, seperti tidak menggunakan kemasan sachet kecil (sampo/ minyak goreng/sabun/teh instan) dan langsung membeli dalam kemasan besar. Contoh lain adalah mengingatkan anggota keluarga untuk membawa rantang atau tempat makanan lainnya daripada membawa plastik curah untuk wadah makanan.

\section{Permodelan Pengelolaan Sampah Permukiman Berbasis Komunitas}

Systems thinking merupakan suatu cara berpikir tentang sistem sebagai jaringan yang saling berhubungan yang mempengaruhi sejumlah komponen yang telah ditetapkan dari waktu ke waktu [18]. Analisis kebutuhan yang dilakukan mengungkapkan beberapa kebutuhan utama stakeholders (Tabel 5). Dinas Lingkungan Hidup memiliki kebutuhan agar seluruh sampah di kota Bogor dapat terangkut. Dari sisi warga/rumah tangga, sampah rumah tangga ingin segera diambil setiap hari (tanpa ada jeda hari pengambilan), dan tidak mau rumahnya kotor karena mengolah sampah di rumah sendiri. Bank Sampah Unit memerlukan sampah masyarakat yang telah disortir dan dibersihkan lebih lanjut agar dapat diterima oleh BASIBA. Harga jual ke BASIBA/industri penampung juga dinilai masih belum transparan.

Keterlibatan pihak pemulung/lapak menunjukkan bahwa selain bersaing dengan Bank Sampah, pemulung dan pelapak hanya mengambil sampah yang laku dijual ke pelapak. Di satu sisi hal ini menunjukkan bahwa apabila ada sistem alur penjualan yang dapat dimonitor dan dimanfaatkan oleh Bank Sampah secara maksimal, maka dapat mengatasi kebutuhan pemulung dan Bank Sampah sekaligus mengenai harga yang lebih baik.

Tabel 5. Analisis Kebutuhan Pelaku dalam Manajemen Pengelolaan Sampah di Kota Bogor.

\begin{tabular}{lll}
\hline No & Pelaku & Kebutuhan \\
\hline 1. & Dinas Lingkungan Hidup & - Kuantitas sampah terangkut ke TPA berkurang \\
& & - Sampah dalam kota terangkut $100 \%$ \\
& & - Pengelolaan Bank Sampah berjalan dengan baik \\
& & - Sampah R3 konstan dan banyak \\
& & - Peningkatan harga beli sampah Daur Ulang \\
& Bank Sampah Unit & - Industri mau menampung sampah R3 yang terkumpul \\
& & - Partisipasi warga meningkat \\
& & - Setoran sampah PET konstan dan banyak \\
3. $\quad$ Bank Sampah Induk Berbasis & - Harga jual sampah plastik PET tinggi \\
& Aparatur & - Sampah terangkut 100\% (tidak ada sisa) \\
4. & Rumah Tangga & - Sampah diangkut setiap hari \\
& & - Tidak repot (jika diminta mengolah) \\
& & - Harga plastik lebih tinggi \\
5 & Pemulung & - Sampah Plastik Rumah Tangga tidak diberikan ke Bank Sampah \\
\hline
\end{tabular}

Sumber: Pengolahan Data (2019) 
Asumsi yang digunakan dalam penelitian ini adalah menyederhanakan timbulan sampah per orang. Dengan demikian untuk anak kecil, dewasa hingga orang tua diasumsikan menghasilkan bobot timbulan harian yang sama. Angka pengangkutan diasumsikan sebagai persentase konstan yang disebutkan oleh pihak DLH Kota Bogor [7] yakni sebesar 74\%. Penelitian ini mengasumsikan daya serap sampah non organik pemulung sebagai $1 \%$ di semua wilayah. Untuk semua sampah yang tersisa (tidak terangkut) diasumsikan sebagai sampah rumah tangga.

Untuk melihat keterkaitan dan umpan balik unsur-unsur yang membangun model pengelolaan sampah rumah tangga ini, mempelajari perilakunya serta menguji efek dari perubahan-perubahan atau dampak kebijakan yang diterapkan pada struktur model, digunakan stock flow diagram (Gambar 7).

Simulasi merupakan prosedur kuantitatif yang menggambarkan suatu proses dengan mengembangkan suatu model. Serangkaian uji coba terencana dilakukan untuk memprediksi tingkah laku proses sepanjang waktu sehingga analisis dapat dilakukan untuk sistem baru tanpa membangun ulang atau mengubah sistem yang telah berjalan.
Dengan demikian, analisis tidak menganggu operasional sistem eksisting(18). Analisis Causal Loop Diagram menunjukkan current situation serta empat alternatif skenario yang memungkinkan untuk dilaksanakan. Penjelasannya adalah sebagai berikut:

a. Current situation merupakan kondisi nyata yang saat ini berjalan,

b. Skenario 1 yakni menambah kapasitas bank sampah sebesar $10 \%$ untuk memenuhi kebutuhan Bank Sampah Unit akan kebutuhan sampah daur ulang yang ditampung,

c. Skenario 2 mengoptimalkan bank sampah yang tidak aktif hingga mencapai 90 unit bank sampah aktif, memenuhi kebutuhan Bank Sampah Induk akan sampah daur ulang yang konstan dalam jumlah banyak serta menurunkan Jumlah Sampah ke TPA,

d. Skenario 3 menurunkan timbulan sampah individu sebesar $10 \%$, dengan tujuan mengurangi kuantitas sampah total yang dihasilkan dan diangkut ke TPA, dan

e. Skenario 4 menambah komposter pengadaan pemerintah hingga 4 kali lipat (600 buah) agar sampah organik dapat terserap dan mengurangi sampah total ke TPA.

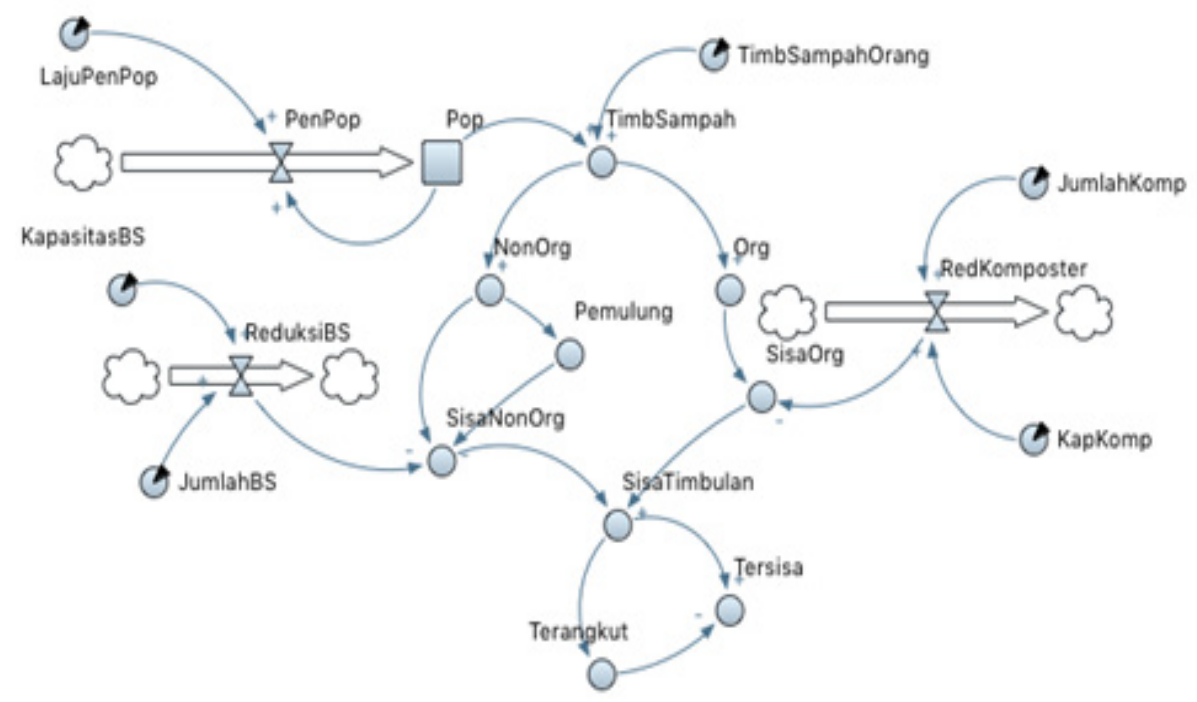

Gambar 7. Stock - flow diagram permodelan pengelolaan sampah perkotaan 
Dari hasil analisis current situation diketahui bahwa timbulan sampah kota Bogor yang saat ini tersisa setelah adanya kegiatan reduksi adalah sebanyak 20.989 ton per bulan dengan didominasi sampah organik sebesar sekitar 13.000 ton. Dari sisa timbulan sampah tersebut, 5.457 ton per bulan (atau sekitar 182 ton/hari) tidak dapat terangkut oleh armada pengangkutan dan masih tersisa di dalam kota Bogor.

Simulasi 1 menunjukkan bahwa penambahan kapasitas bank sampah sebanyak $10 \%$ akan mereduksi sampah yang tersisa (tidak terangkut) sebanyak 0,60\% pada tahun pertama, kemudian $1,24 \%$ pada tahun kedua dari kondisi saat ini, hingga $3,18 \%$ pada tahun kelima. Simulasi 2 akan mereduksi $0,62 \%$ pada tahun pertama dan $1,25 \%$ pada tahun kedua, hingga $3,19 \%$ pada tahun kelima. Reduksi sebesar 18,08\% diprediksi akan terjadi pada skenario 3 pada tahun kelima, dimulai dari reduksi 15,9\% pada tahun pertama. Penambahan komposter sebagai skenario 4 diprediksi berhasil mengurangi $0,71 \%$ sampah tidak terangkut pada tahun pertama, dan $3,3 \%$ pada tahun kelima. Tabel 6 menunjukkan potensi reduksi selama lima tahun dari masing-masing skenario dibandingkan dengan kondisi saat ini.

Berdasarkan penelitian yang telah dilakukan, diketahui bahwa skenario ketiga, yakni mengurangi timbulan sampah per orang per hari (reduce waste generation) merupakan skenario yang memiliki dampak reduksi sampah tersisa paling signfikan di
Kota Bogor. Hasil ini sesuai dengan tingkatan pengolahan dan reduksi sampah [1] yang menekankan bahwa hierarki tertinggi dan paling efektif untuk mengurangi timbulan sampah adalah melalui reduce (reduksi) timbulan sampah yang dihasilkan oleh masyarakat. Pemerintah kota Bogor telah mengeluarkan Peraturan Walikota Nomor 61/2018 tentang Pengurangan Penggunaan Kantong Plastik. Regulasi ini diharapkan mampu untuk menekan jumlah pengunaan kantong plastik oleh pelaku usaha, pusat perbelanjaan maupun toko modern. Pada akhirnya mengurangi timbulan sampah plastik di masyarakat, karena sampah plastik jenis PP berkontribusi sebesar 36,61\% dari seluruh jenis sampah plastik di Kota Bogor [20].

Skenario ketiga penelitian ini sejalan dengan UU Nomor 18/2008, dimana pengelolaan sampah rumah tangga dan sampah sejenis sampah rumah tangga dimulai dari sumbernya. Agar skenario ini dapat berjalan, maka Pemerintah Kota diharapkan melakukan sosialisasi pemahaman mengenai timbulan sampah dan cara-cara pengurangan sampah secara berkelanjutan di sekolah dan lembaga pendidikan. Kampanye untuk mengurangi sampah dari sumbernya dilakukan melalui gerakan pilah sampah dari rumah menggunakan tong sampah khusus yang juga berfungsi sebagai sarana edukasi daur ulang dan komposting [21]. Kanal-kanal media sosial digunakan sesuai dengan karakteristik usia masyarakat yang disasar untuk membentuk persepsi dan

Tabel 6 Proyeksi Reduksi Skenario Selama 5 Tahun

\begin{tabular}{ccccc}
\hline Tahun & Skenario 1 & Skenario 2 & Skenario 3 & Skenario 4 \\
1 & $0.6 \%$ & $0.6 \%$ & $15.9 \%$ & $0.7 \%$ \\
2 & $1.2 \%$ & $1.2 \%$ & $16.4 \%$ & $1.4 \%$ \\
3 & $1.9 \%$ & $1.9 \%$ & $17.0 \%$ & $2.0 \%$ \\
4 & $2.5 \%$ & $2.5 \%$ & $17.5 \%$ & $2.6 \%$ \\
5 & $3.2 \%$ & $3.2 \%$ & $18.1 \%$ & $3.3 \%$ \\
\hline
\end{tabular}

Sumber: Pengolahan Data (2019) 
meningkatkan partisipasi masyarakat dalam mereduksi sampah yang mereka hasilkan [22] [23]. Penegakan hukum (law enforcement) juga perlu diperkuat melalui sanksi tegas dan konsisten terhadap masyarakat yang membuang sampah sembarangan. Langkah ini menyasar lingkungan/perumahan yang tidak memperhatikan pengelolaan sampahnya dan tidak berpartisipasi aktif mengelola sampah padat rumah tangganya [20].

\section{SIMPULAN}

Partisipasi masyarakat di Kota Bogor masih tergolong rendah, baik dalam partisipasi pengolahan sampah berbasis komunitas, maupun partisipasi mengurangi timbulan sampahnya sendiri. Faktor pendidikan serta usia berpengaruh positif dan signifikan terhadap partisipasi masyarakat. Untuk partisipasi masyarakat dalam mereduksi timbulan sampah, tidak ada variabel yang signifikan berpengaruh. Permodelan masing-masing skenario menghasilkan angka reduksi sampah tersisa yang bervariasi. Reduksi tertinggi dihasilkan oleh skenario ketiga dan mampu mengurangi $18,08 \%$ sampah yang tidak terangkut. Dengan mengurangi jumlah sampah yang ditimbulkan per orang akan memiliki dampak signifikan terhadap pengurangan total timbulan sampah harian yang dihasilkan, dan pada akhirnya mengurangi jumlah sampah yang tidak terangkut.

\section{DAFTAR PUSTAKA}

1. Pharino C. Household Hazardous Waste Management in Thailand. 2017. 63-76 p.

2. Bogor BPSK. Bogor City in Figures 2017. 2017;244. Available from: http:// bappeda.kotabogor.go.id/images/produk/ 4de0bc9a76f6200a5697c197c8eb250e.pdf

3. Bogor BPSK. Bogor City in Figures 2018. Vol. 1, Kota Bogor Dalam Angka Bogor Municipality In Figures 2018. 2018. 1-416 p.
4. Bogor BPSK. Bogor City in Figures 2015. 2015.

5. Negara S. Pengelolaan Sampah - UU no. 18 tahun 2008. Indonesia: Sekretariat Negara Republik Indonesia; 2008 p. 1-37.

6. Asteria D, Heruman H. Bank Sampah Sebagai Alternatif Strategi Pengelolaan Sampah Berbasis Masyarakat Di Tasikmalaya (Bank Sampah (Waste Banks) as an Alternative of CommunityBased Waste Management Strategy in Tasikmalaya). J Mns dan Lingkung. 2016;23(1):136.

7. Bogor DLHK. Dokumen Informasi Kinerja Pengelolaan Lingkungan Hidup Daerah Kota Bo. Bogor; 2017.

8. Yogiesti V, Hariyani S, Sutikno FR. Pengelolaan Sampah Terpadu Berbasis Masyarakat Kota Kediri. J Tata Kota dan Drh. 2010;2(2):95-102.

9. Bappeda Kota Bogor. Pemetaan Aspek Teknis Sistem Pengelolaan Sampah Kota Bogor. Lap Akhir Layanan Persampahan Kota Bogor. 2014;0834.

10. BOGOR SDK. Pengurangan Penggunaan Kantong Plastik. 61 Indonesia: Berita Daerah Kota Bogor; 2018.

11. Cochran WF. Sampling Techniques. In: Sampling Techniques. 3rd ed. Toronto: John Wiley \& Sons, Inc; 1977. p. 10.

12. Ratiabriani N, Purbadharmaja I. Partisipasi Masyarakat dalam Program Bank Sampah: Model Logit. J Ekon Kuantitatif Terap. 2016;9(1):53-8.

13. Ramandhani TA. Analisis Timbulan dan Komposisi Sampah Rumah Tangga di Kelurahan Mekar Jaya (Depok) Dihubungkan dengan Tingkat PendapatanPendidikan-Pengetahuan-Sikap-Perilaku Masyarakat. 2011;Tugas Akhir. Fakultas Teknik. Program Studi Teknik.

14. Maharani S, Suarna I, Budiarsa Suyasa I. Karakteristik Sampah Dan Persepsi Masyarakat Terhadap Pengelolaan Sampah Di Kecamatan Banyuwangi Kabupaten Banyuwangi Provinsi Jawa Timur. Ecotrophic J Environ Sci. 2012;2(1).

15. Setyowati R, Mulasari SA. Pengetahuan dan Perilaku Ibu Rumah Tangga dalam 
Pengelolaan Sampah Plastik. Kesmas Natl Public Heal J. 2013;7(12):562.

16. Asmara B, Kurniawan A. Persepsi Masyarakat Terhadap Sampah Dan Pengelolaan Sampah Di Kabupaten Karanganyar (Kasus di Kecamatan Karanganyar dan Tawangmangu). J Bumi Indones. 2015;4(3).

17. Surjandari I, Hidayatno A. Model Dinamis Pengelolaan Sampah Untuk Mengurangi Beban Penumpukan. J Tek Ind. 2009;11(2):134-147.

18. Hardjomidjojo H. Sistem Dinamik: Konsep Sistem dan Pemodelan untuk Industri dan Lingkungan. Bogor: SEAMEO Biotrop; 2007.
19. Suzianti A, Humaira S, Anjani S. Macroergonomic Approach for Improving the Municipal Waste Management System in Jakarta. Int J Innov Manag Technol. 2013;4(6).

20. Setiadi A. Studi Pengelolaan Sampah Berbasis Komunitas pada Kawasan Permukiman Perkotaan di Yogyakarta. 2015;3(April):27-38.

21. Puspitawati $Y$, Rahdriawan M. Kajian Pengelolaan Sampah Berbasis Masyarakat dengan Konsep 3R (Reduce, Reuse, Recycle) di Kelurahan Larangan Kota Cirebon. J Pembang Wil Kota. 2012;8(4):349. 